\title{
A música e os músicos como problema sociológico
}

Music and Musicians as a Sociological Issue

La musique et les musiciens comme problème sociologique

Luís Melo Campos

\section{OpenEdition}

\section{Journals}

Edição electrónica

URL: http://journals.openedition.org/rccs/756

DOI: $10.4000 /$ rccs.756

ISSN: 2182-7435

\section{Editora}

Centro de Estudos Sociais da Universidade de Coimbra

Edição impressa

Data de publição: 1 Outubro 2007

Paginação: 71-94

ISSN: 0254-1106

Refêrencia eletrónica

Luís Melo Campos, "A música e os músicos como problema sociológico », Revista Crítica de Ciências Sociais [Online], 78 | 2007, colocado online no dia 01 outubro 2012, criado a 19 abril 2019. URL : http:// journals.openedition.org/rccs/756; DOI : 10.4000/rccs.756 


\section{LUÍS MELO CAMPOS}

\section{A música e os músicos como problema sociológico}

Debatem-se alguns problemas que se colocam ao estudo do universo musical enquanto objecto de análise sociológica: primeiro, discutem-se possíveis delimitações do objecto; depois, equaciona-se o problema da música enquanto objecto e veículo de sentido; finalmente, alinha-se um questionamento dirigido aos universos socioculturais dos músicos.

\section{Introdução}

Apesar de uma significativa presença nas mais variadas circunstâncias, momentos e contextos da vida social, quer como objecto de consumo, quer como adereço de situações e ambientes (por exemplo, o cinema e a publicidade audiovisual raramente a dispensam), a música tem sido uma das artes menos estudadas pelas ciências sociais, designadamente pela sociologia. O facto de se tratar de uma das mais abstractas formas de expressão artística, a sua natureza eventual, indissoluvelmente ligada ao tempo, e incorpórea (quiçá por isso mesmo uma das artes que mais desenvolveu sistemas internos de codificação), explicará algumas dificuldades da sua abordagem e o carácter menos sistemático do seu estudo sociológico. Dificuldades que se fazem mais particularmente sentir quando se perspectiva a actividade musical pelo lado da criação, da produção de práticas e objectos musicais, e um pouco menos quando se aborda pelo lado da recepção e dos públicos, já que aqui é possível elidir alguns problemas (que a especificidade interna dos objectos e práticas musicais conhecem) através de temáticas como o lazer, os usos e consumos, os padrões e identidades culturais, enfim, deslocando o escopo analítico para as funções sociais e culturais que tais práticas compreendem; deslocação que se verifica também quando se analisa a produção musical focalizando, por exemplo, a indústria discográfica e o funcionamento económico do mercado, deixando de lado a análise dos actores e dos processos socioculturais mais directamente implicados na criação de objectos e práticas musicais. 
No entanto, a quantidade e diversidade de práticas, valores e representações sociais associadas às fruições musicais (quer no plano da criação e produção, quer no plano dos consumos, utilizações e apropriações) certamente merecem um olhar sociológico, e o escasso tratamento da música pelas ciências sociais justificaria por si só o incentivo do seu estudo. É razoavelmente consensual que a música pode evocar ou suscitar sensações e emoções, predispor à acção ou à reflexão, e mesmo que pode veicular significados, incorporar e promover sentido, para além de constituir forte enzima de sociabilidade mesmo que (ou também porque) frequentemente suscite acaloradas polémicas. Mas quais são os exactos contornos desta ferramenta comunicativa tão recorrentemente presente no quotidiano? E como poderão avaliar-se os processos socioculturais implicados na sua formatação? Sem pretender ser exaustivo, este artigo equaciona alguns problemas que se colocam ao estudo do universo musical enquanto objecto de análise sociológica.

Num texto que tem constituído referência, Diana Crane (1994) identifica duas tendências teóricas particularmente profícuas no panorama da sociologia da cultura. Uma delas pode globalmente designar-se por teorias da recepção, na medida em que enfatiza as disputas sociais em torno dos significados dos textos/discursos (designadamente nos processos de comunicação que envolvem os media, mas não só), sublinhando o seu carácter instável e contestável e, portanto, a possibilidade de poderem ser interpretados e usados em moldes não conformes, e por vezes opostos, às intenções dos autores. ${ }^{1}$ A segunda tendência é a chamada perspectiva da produção, que examina as relações entre os processos socioculturais subjacentes à produção de elementos simbólicos e as respectivas características culturais desses mesmos produtos. ${ }^{2}$ Como se verá, estas duas fontes de inspiração e formatação teórica parecem estar de algum modo presentes em muitas das abordagens sociológicas que constroem o seu objecto teórico através de algum questionamento em torno da música.

\section{A música como objecto sociológico}

O desenvolvimento de uma linha sociológica de questionamento em torno da música coloca alguns problemas. Um primeiro consiste em saber de que se fala quando se fala de música. É verdade que qualquer comum dicionário fornecerá uma definição aceitável, mas a questão é menos simples do que parece, por exemplo: música é uma arte que se expressa mediante a

\footnotetext{
${ }^{1}$ Sobre este assunto pode ver-se Press, 1994, e Bowler, 1994.

2 Sobre a perspectiva da produção pode ver-se Peterson, 1994.
} 
ordenação dos sons no tempo. Nesta definição, sublinha-se a existência de som, seja ele qual for, e a sua ordenação no tempo, o que faz supor que existe algo ou alguém que ordene e a ideia de ritmo (ordem no tempo). O requisito do ritmo é, aliás, uma ideia cara a muitos autores. Por exemplo, António Victorino d'Almeida é categórico: "Porque sem ritmo não há música, nenhuma espécie de música!” (1993: 23). Entretanto, fica por saber o que é o som (alguns compêndios de acústica distinguem som de ruído, atendendo à regularidade ou não do fenómeno vibratório que está na origem de um e de outro), assim como fica por saber, porventura com maior margem de indeterminação, o que é a arte.

Alguma perplexidade surgirá a propósito da peça 4' 33", na medida em que John Cage propôs ao público quatro minutos e trinta e três segundos de silêncio. Trata-se de uma obra que pode ser interpretada por solistas ou por conjuntos orquestrais de estrutura e dimensão variáveis, o que não é indiferente para o resultado final (patente nas diferentes versões editadas da peça), ${ }^{3}$ já que o silêncio possível num solo absoluto é certamente diferente do silêncio possível de uma orquestra sinfónica. Para além disso, as versões ao vivo diferenciam-se também pelo comportamento do público, mais ou menos inquieto, com maior ou menor propensão a tosses, pigarros, comentários, etc. A modulação do silêncio é muito provavelmente aquilo a que o compositor convida, contudo, esta modulação não é organizada nem tem ritmo, e, por isso, segundo aquela definição, retirada do mais próximo dicionário, e segundo Victorino d'Almeida, não seria música. ${ }^{4}$

Por outro lado, a peça 4' 33" constitui de algum modo um questionamento sobre a noção tradicional de obra artística/musical, assim como da noção de artista que lhe é correlata. Questionamento que não se verifica

\footnotetext{
${ }^{3}$ Desta obra musical existem pelo menos dois registos fonográficos: uma versão de David Tudor, editada em 1952 pela Cramps Records (vinil), e uma versão pelo Amandina Percussion Group dirigido por Zoltan Kocsis, editada pela Hungaraton em 1988 (CD).

${ }^{4}$ Ainda que necessariamente imperfeita, uma definição de música que consegue evitar um conjunto de censuras correntes sem cair nas expeditas definições (actualmente em voga) que remetem para a multiplicidade de entendimentos possíveis por parte dos actores a parametrização dos objectos a definir, poderá equacionar-se assim: música seria um conjunto organizado de sons em movimento, articulado em moldes não exclusivamente decorrentes de idiomas linguísticos, produzido e percebido como intencional, o que significa que a música é sempre um artefacto e nunca resultado do acaso (não há música natural nem puramente aleatória); que a música é produto de uma actividade projectiva, mais ou menos consciente, e que compreende uma dimensão comunicacional em que a actividade projectiva é, pelo menos, percebida como tal por eventuais receptores; e ainda que, a ser assim, a música pressupõe um conjunto de convenções que permite algum nível de interpretação comum, podendo dizer-se que o conjunto de convenções que tornam o projecto comunicável constitui um sistema musical e que as qualidades que se atribuem à música estão relacionadas com a construção e as interpretações desse projecto - definição inspirada em Abraham Moles (1958) e Roland de Candé (2003).
} 
apenas no campo musical mas também noutros campos artísticos. No domínio das artes plásticas, Alexandre Melo refere o caso das esculturas ready-made (a primeira terá sido uma roda de bicicleta colocada sobre um banco) e, à semelhança de Cage, representando também a queda de todos os limites, a exposição de Yves Klein em 1958: apresentou uma galeria vazia e vendeu zonas de sensibilidade pictórica imaterial (Melo, 2000).

A verdade é que, perante alguns artefactos propostos por artistas hodiernos, os próprios conceitos de arte e de objecto artístico tornam-se bastante indeterminados, não apenas pelas características dos objectos (e práticas) propostos como artísticos, mas também porque se supõe um envolvimento activo por parte dos receptores. Nas palavras de Umberto Eco:

A obra de arte vai-se tornando, de Joyce à música serial, da pintura informal aos filmes de Antonioni, cada vez mais uma obra aberta, ambígua, que tende a sugerir não um mundo de valores ordenado e unívoco, mas um leque de significados, um campo de possibilidades, e para chegar a isto requer-se cada vez mais uma intervenção activa, uma escolha operativa por parte do leitor ou espectador. (Eco, 1972: 273)

Seguindo Alexandre Melo:

Hoje em dia, não há quaisquer limites formais para aquilo que é susceptível de ser considerado uma obra de arte. O problema não é não existirem critérios objectivos, que já se sabe que não existem, para avaliar obras de arte: não podem existir sequer critérios gerais, enunciáveis. Então, temos de inventar, de cada vez, as razões para valorizar uma obra de arte. (Melo, 2000)

Em síntese, a percepção cognitiva e mesmo a reflexividade dos actores sociais parecem, pois, constituir componentes cada vez mais explicitamente convocadas e não negligenciáveis na relação entre autores, respectivas práticas artísticas e públicos.

No entanto, a história das artes (e da música) tem revelado importantes transformações em diversos planos da sua possível avaliação. Na Antiguidade Grega, por exemplo, a palavra música era uma forma adjectivada de musa, qualquer uma das nove Deusas que presidiam a determinadas artes e ciências; segundo a mitologia grega, a música era de origem divina, designadamente os seus inventores e primeiros intérpretes (Apolo, Anfião e Orfeu), e as pessoas acreditavam que a música tinha poderes mágicos: que era capaz de curar doenças, purificar o corpo e o espírito e operar milagres no reino da Natureza (Grout e Palisca, 1997: 17-22). Curiosamente, também no Antigo Testamento se verifica uma articulação entre música e poderes divi- 
nos: David cura a loucura de Saul tocando harpa; o som das trombetas e a vozearia derrubaram as muralhas de Jericó (exemplos referidos por Grout e Palisca, 1997: 17). No mesmo sentido se expressou Martinho Lutero numa carta dirigida a Ludwig Senfl (1530): "Repare-se que os Profetas não recorreram à Geometria, nem à Aritmética, nem à Astronomia, mas somente à Música, para nos fazerem ouvir a verdade. Os Profetas falavam por meio de salmos e canções..." (apud Herzfeld, s/d: 262).

Tratando-se de uma prática ancestral (e, para os crentes, porventura divina), são múltiplas as especulações e escassas as certezas relativas às origens da música. Mais seguro é o reconhecimento de que, durante um longo período da história da civilização ocidental, a produção e as práticas musicais de carácter mais erudito estiveram adstritas a contextos socioculturais muito específicos, designadamente do foro religioso e da corte. E também aqui com aspectos virtualmente "mágicos". Santo Ambrósio (340-397), Bispo de Milão, escreveu: "Enquanto, durante a leitura dos textos, todos conversam, calam-se todos e põem-se a cantar logo que o salmo é entoado" (apud Herzfeld, s/d: 262).

É particularmente curiosa a apreciação (estética?) de Christopher Small sobre a Paixão Segundo São Mateus de Johann Sebastian Bach. Small refere-se à impossibilidade de a ouvir por atenção à força com que incorpora um mito que lhe é antipático. Censurando esta atitude, os amigos sugeremlhe: limita-te a ouvir a maravilhosa música. Maravilhosa será, mas para quê? Seguindo Small, o próprio Bach poderia muito bem achar que a sua obra-prima está sendo trivializada, quando foi composta para ser ouvida num contexto específico: as exéquias de Sexta-feira Santa da Igreja Luterana (Small, 1998: 7).

A atitude dos amigos de Small é representativa de uma outra relação com a música: um produto de fruição estética mercantilizado e independente de um contexto sociocultural e funcional específico. No plano da análise histórica, a deslocalização da música para um contexto de relações entre artistas e públicos, que actualmente parece constituir a modalidade dominante da fruição musical, tem sido equacionada como expressão da emergência do romantismo enquanto paradigma estético, por um lado, e da ascensão da burguesia enquanto classe que se opõe e sobrevém à aristocracia do Antigo Regime, por outro. Tendo surgido no século XVII, foi já nos séculos XVIII e XIX que se assistiu à multiplicação de teatros de ópera e de concertos públicos (instituindo a prática musical como produto de mercado com entradas pagas), e que a arte da música foi adquirindo os contornos que hoje conhecemos, que consideramos naturais e com que lidamos. 
No entanto, alguns estudiosos referem-se à Grécia Antiga como o tempo e o lugar em que é possível encontrar as primeiras manifestações de um público socialmente consciente, cujo juízo podia ser determinante no contexto dos grandes espectáculos-concursos de música realizados em Delfos e em Atenas. A conquista romana e, sobretudo, a ascensão social e política do cristianismo, estarão na base de um refluxo a favor de uma música mais erudita, apanágio da Igreja e dos poderes, que já só se destina ao povo para efeitos da sua edificação ou salvação, e que perdurou até aos séculos XVII e XVIII (Candé, 2003: 20). Compreender-se-á que não é aqui o lugar adequado para explanar e dirimir os complexos processos implicados no evoluir do espaço social ocupado pelas práticas musicais ao longo da história. Certo parece ser que, nas sociedades hodiernas, já não tendo uma função social predeterminada, a actividade musical profissional tornou-se um produto comercial, de fabrico mais artesanal ou mais industrial, e encontra-se disponível para fruição e consumo das populações nos mais diversos tempos e espaços de uso e apropriação sociocultural.

Apesar das transformações que a fruição e a percepção musicais certamente conheceram ao longo dos tempos, Johann Wofgang von Goethe referiu-se à música em termos que evidenciam duas dicotomias que permanecem actuais (popular/erudito; corpo/espírito): "A seriedade da música religiosa, os aspectos alegres e trocistas da música popular, são os dois pólos opostos entre os quais a arte dos sons sempre tem oscilado. É servindo a estes dois fins, a religião [o espírito] ou a dança [o corpo], que a música se tem tornado duradouramente indispensável" (apud Herzfeld, s/d: 264).

Embora grande parte da análise musicológica tome a tradição ocidental erudita por objecto exclusivo (por vezes acrescida de desenvolvimentos e tendências hodiernas dessa mesma tradição), de um ponto de vista sociológico não faz sentido negligenciar toda uma série de práticas musicais (normalmente rotuladas de populares) em favor daquela, por maior que seja a sua mais valia estética ou académica. Desde logo, porque não compete à sociologia (ou a qualquer outra ciência social) decidir se a música clássica é ou não expressão de um elevado empenhamento da alma humana, embora esta questão possa ser crucial para muitos músicos e ouvintes e, enquanto tal, possa eleger-se como objecto de uma análise orientada para o discernimento do sentido que os actores emprestam às suas práticas. Mas o mesmo poderia dizer-se a propósito dos blues enquanto representação do choro ou da dor de uma cultura oprimida. Mais sociologicamente pertinente será questionar como se desenvolveram e quando se tornaram culturalmente dominantes ou mais significativos certos géneros (como a música clássica) ou como e quando remanescem marginais (como os blues), perceber quando 
e como tais ou outros argumentos se desenvolvem e cristalizam, quem os defende, quem compõe ou interpreta o quê e quem ouve. Nesta perspectiva diz-nos K. Boehmer:

Ao contrário da musicologia tradicional a sociologia da música não reconhece diferenças estéticas na arte musical, na música popular ou noutras formas musicais mais recentes; encara estas categorias de um ponto de vista sócio-histórico e analisa as condições em que certas classes ou estratos sociais [...] produzem e consomem diferentes idiomas e formas musicais [...]. Outra diferença entre a musicologia tradicional e a sociologia da música é que esta parte da relevância social do consumo musical e não de alegadas qualidades estéticas ou formais do produto musical. [E a verdade é que] a música não clássica representa mais de $90 \%$ de toda a produção e consumo musical. (Boehmer, 1980: 433)

A este propósito, fará sentido adoptar desde já uma perspectiva nominalista, sublinhando que, antes de ser uma coisa, ou melhor, uma abstracção, a noção de música remete sobretudo para uma actividade, para algo que as pessoas fazem, e que os contornos dessa realidade tendem a encobrir-se ou mesmo a desaparecer quando o olhar analítico se prende numa reificação conceptual: a música.

Christopher Small, por exemplo, utiliza a expressão musicking (musicar) no sentido de sublinhar que o seu objecto de análise não é tanto a música, mas sim as pessoas que a ouvem ou compõem, que tocam, cantam e mesmo as que dançam, assim como as formas como o fazem e as razões que presidem a tais práticas, as relações sociais e culturais que elas implicam e as experiências sensoriais e cognitivas que elas constituem (Small, 1998). Nesta perspectiva, a pergunta "qual o sentido da música?" perde significado, devendo substituir-se por "qual o sentido desta peça (ou destas peças) de música?", o que não é a mesma coisa. Mais, nesta perspectiva, a questão verdadeiramente relevante passa a ser: o que é que se passa aqui (com esta música e estas pessoas, neste momento e neste local)? Seguindo Small, o acto de musicar estabelece no lugar em que acontece uma série de relações e seria nessas relações que deveria procurar-se o seu sentido: não apenas entre aqueles sons organizados que são convencionalmente pensados como o material do sentido musical, mas sobretudo entre as pessoas que tomam parte na performance, seja em que qualidade for (desde o compositor e o intérprete até ao ouvinte, passivo ou activo, e mesmo todos aqueles que também estão envolvidos, por exemplo, através da produção de concertos, da manutenção e transporte de instrumentos, do funcionamento dos espaços de actuação, etc.). Só compreendendo o que as pessoas fazem quando 
tomam parte numa performance seria possível compreender a natureza da música, o sentido que lhe é atribuído e como é vivida (Small, 1998).

Neste contexto, faz sentido relativizar a ideia enraizada de que o sentido das obras de arte reside em si mesmas. Ideia que, no caso da música, certamente se associa à reificação da partitura que a tradição erudita ocidental acabou por promover. Ao transformar um instrumento de comunicação ou um projecto de execução - a partitura, que não é um objecto acabado, mas sim um esboço mais ou menos completo de uma obra a fazer - num cânone fixo que deve respeitar-se, acabou também por favorecer-se um culto desmesurado da obra musical escrita (Candé, 2003). Como noutro contexto denunciou Ferdinand de Saussure, assinala-se aqui o perigo de a escrita contaminar a língua. A verdade é que se trata de uma ideia recorrentemente presente no discurso comum e que se traduz, por exemplo, na expressão "saber música", que se refere sobretudo à capacidade de conhecer um código escrito e não tanto à capacidade de criar ou executar ideias musicais.

De qualquer modo, seguindo Mário Vieira de Carvalho, é no pós-guerra que aparecem as primeiras obras de fundo do que é ou pode ser uma sociologia da música:

As diferenças que nela se manifestam quanto a questões de teoria e de método, quanto à definição do próprio objecto da nova disciplina científica polarizam-se em Silbermann (1957) e Adorno (1962): o primeiro a excluir o objecto artístico do seu campo de observação (só as condições da vida musical seriam de considerar), o segundo a definir a decifração sociológica da obra musical como objecto central da sociologia da música; um aceitando a fronteira estabelecida pela estética da autonomia [artística, neste caso, especificamente musical], o outro recusando-a, ao postular que a construção interna da obra de arte carece do que não é arte, exactamente na mesma medida em que transmite o que não é arte. (Carvalho, 1991: 40-41)

Ao sublinhar a dimensão cultural da música, alguns autores são mesmo provocatórios, por exemplo: "Na música o som até é secundário [...] Música é comportamento regulado, não é som” (Merriam, 1964: 27); "O que é que a música tem que ver com o som?” (Charles Ives, apud Carvalho, 1991). Aquela afirmação ou esta última pergunta levantam questões que têm tanto de incompreensível para a musicologia tradicional como de razoável para algumas áreas das ciências sociais. Como diz Mário Vieira de Carvalho:

O que suscita a resistência da musicologia instituída não é que a sociologia se ocupe da música, é antes que a musicologia se torne sociológica. Porque a tarefa que se 
coloca à musicologia será, neste caso, proceder à desconstrução do próprio paradigma que lhe deu origem (o princípio da autonomia estética) reconhecendo o carácter ideológico desse paradigma. (Carvalho, 1991: 39)

A secundarização do som constitui porventura um importante passo de ruptura epistemológica com o conhecimento decorrente da familiaridade com o objecto. No entanto, como preconiza Hennion (1993), valerá a pena ultrapassar o dualismo entre análises internas e externas, racionalizações e denúncias sociais do objecto artístico, o que implica ter em devida conta as mediações próprias da arte, quer no seu estatuto teórico quer como realidade empírica. Para Hennion, trata-se de empreender uma sociologia que procure conhecer o social na arte, e não tanto o conhecimento da arte. ${ }^{5}$ Neste sentido, também Hennion (1993) sublinha o conjunto de dispositivos (intérpretes, instrumentos, pautas, sistemas de amplificação de som, salas de concerto ou formas de registo, produtores, etc.) que a música utiliza para existir e que as vivências da música não são independentes dos diferentes dispositivos que em cada situação são accionados, e avança a ideia de música como mediação e mesmo da sociologia da música enquanto sociologia da mediação. Por outro lado, sem desqualificar qualquer das duas razões opostas que conduzem as análises ora para o reconhecimento da transcendência do par sujeito-objecto (tendência individualizante da construção estética), ora para a sociologização da música enquanto máscara de jogos de identidade social (tendência da sociologia para o colectivo), Hennion propõe-se tomar aqueles vectores como limites de qualquer tentativa de explicação:

Tentaremos reconhecê-los mas sem os utilizar como recurso explicativo. A regra do jogo é fácil de enunciar e de cumprir: é interdito utilizar aqueles dois registos opostos e cúmplices como recurso explicativo, o reconhecimento da música como transcendente e a sua denúncia como crença constitutiva do grupo social. (Hennion, 1993: 21)

No sentido de encetar a discussão em torno da música como objecto de análise sociológica, vale a pena sublinhar alguns contributos da chamada perspectiva da produção. No essencial, pode dizer-se que a perspectiva da produção propõe uma inversão de sentido no escopo analítico: ao invés de externalizar a análise de práticas e objectos culturais (designadamente musicais), focalizando as relações entre tais práticas e factores que lhes são exter-

\footnotetext{
${ }^{5}$ No mesmo sentido, Howard Becker (1982: xi) afirmou: poderá dizer-se que não fiz sociologia da arte mas haverá que reconhecer que fiz sociologia das ocupações artísticas.
} 
nos (por exemplo, as variáveis de caracterização sociográfica), ${ }^{6}$ propõe um centramento analítico sobre os protagonistas da produção cultural e as relações que estabelecem entre si e com as suas práticas, escarafunchando em profundidade os processos e condições socioculturais implicados na própria produção cultural; deste modo, sociedade e cultura surgem intrinsecamente conectados e já não apenas articulados como se de um espelho se tratasse. Para além disso, a perspectiva da produção assume uma atitude nominalista relativamente aos produtos culturais, o que significa focalizar de igual modo os distintos domínios de produção simbólica e cultural, incluindo a tradicional distinção entre popular e erudito. Na medida em que se trata de analisar processos e condições socioculturais implicados na produção cultural, tais processos e condições são sempre comparáveis entre si, independentemente dos específicos domínios (popular/erudito; cultu$\mathrm{ral} /$ científico; musical/ cinematográfico; etc.) a que respeitam.

\section{A música como veículo de sentido}

O problema da música enquanto objecto, veículo e promotor de sentido constitui uma questão amplamente debatida e que, por isso, vale a pena não elidir. A discussão sobre este tema não é recente e as divergências surgem logo a propósito de saber se é ou não pertinente falar de sentido do discurso musical, e se o é, em que termos?

Segundo Eduard Hanslick (crítico e musicólogo do século XIX), não é razoável discutir o problema do sentido da música aquém ou além da dimensão estética no quadro do próprio discurso musical. Aquilo que um compositor poderia discursar através da manipulação dos sons seriam ideias estritamente musicais. Não se trata de negar que a música possa produzir emoções e sentimentos ou remeter o ouvinte para ideias de natureza não musical, mas de sublinhar que o discurso musical, embora seja uma construção intelectual, se confina ao campo da estética sonora. Para Hanslick (s.d.), uma ideia musical é um fim em si mesma e não um meio de representar sentimentos e pensamentos.

Vale a pena notar que as teses e argumentos de Hanslick emergem a propósito da tradição musical ocidental erudita e que, mesmo no seio dessa tradição, é possível encontrar posições divergentes, designadamente nos

\footnotetext{
${ }^{6}$ Esta linha de análise é normalmente enquadrada por modelos teóricos que substantivam como explicativas certas variáveis particularmente discriminantes, por exemplo as pertenças sociais e os níveis de escolaridade, e tem permitido evidenciar os principais desequilíbrios sócio-estruturais que a esfera da cultura conhece, designadamente as desigualdades no próprio aceso à cultura e sua fruição, assim como efeitos de reprodução desses desequilíbrios em função da própria possibilidade de accionar as práticas culturais como recurso social e da arbitrariedade social presente nos critérios de legitimidade cultural e nas correspondentes hierarquias de bens e actividades.
} 
próprios músicos compositores. Alguns partilham aqueles argumentos, indo mesmo mais longe ao sublinhar a total independência entre música e quaisquer espaços expressivos ou semânticos. Por exemplo, segundo Igor Stravinski (1935): “A música é, pela sua própria natureza, impotente para exprimir o que quer que seja, sentimentos, atitudes de espírito, humor psicológico ou fenómenos da natureza". E, segundo John Cage (1957): "É preciso permitir aos sons serem sons... eles não devem jamais ser portadores duma ideia ou duma associação ao que quer que seja" (apud AA.VV., 1971: 89). Outros, porém, acentuam o valor expressivo da música e sublinham o seu potencial para referir e produzir emoções, por exemplo, Richard Wagner para quem a música pode expressar o indizível em linguagem verbal, ou Ludwig van Beethoven que insistia na relação entre música e filosofia. Para este último compositor, a música estava muito longe de ser uma mera abstracção, música eram ideias, sobretudo ideias (apud Victorino d'Almeida, 1993: 11). Felix Mendelssohn vai mais longe ao expressar-se do seguinte modo:

As pessoas queixam-se frequentemente da ambiguidade da música, que têm muitas dúvidas quanto ao que devem pensar quando a ouvem. No entanto, toda a gente entende as palavras. Comigo é inteiramente o contrário. Não apenas por relação ao conjunto de uma frase, mas também por relação às palavras singulares; estas parecem-me muito ambíguas, muito vagas, e tão facilmente susceptíveis de compreensão errónea em comparação com a música [...]. Os pensamentos que me são expressos numa peça de música de que eu gosto não são indefinidos de forma a não poderem ser verbalizáveis, pelo contrário são muito definidos. (apud Cooke, 1989: 12)

A questão não é, pois, pacífica. Embora se reconheça que a música possui elevado potencial expressivo, que age sobre nós e que é possível verbalizar os efeitos que produz e o que evoca (uma atmosfera, um movimento, um sentimento, uma paisagem, excitação, serenidade), está longe de ser consensual que o discurso musical possua, por si mesmo, potencial significante e, se acaso o possui, como discerni-lo?

Alguns autores, por exemplo Suzanne Langer (1969), empenharam-se em demonstrar que existe um paralelismo entre as propriedades acústicas da música e as propriedades da chamada 'vida interior' (física e mental), e defendem o seu carácter essencialmente emocional. Deryck Cooke é um dos autores que mais investiu na análise e na afirmação de que existem "correspondências naturais entre os efeitos emocionais de certas notas da escala e as suas posições nas [...] séries harmónicas”, sublinhando, designadamente, aspectos como a força da quinta ou o prazer da terceira maior (1989: 25) e argumentando que, na música de base tonal, todos os composi- 
tores utilizaram frases melódicas, harmonias e ritmos muito similares para exprimir ou evocar as mesmas emoções. Segundo Cooke, a música caracteriza-se fundamentalmente pela capacidade de evocar ou exprimir emoções, e, para além disso, a música constitui uma linguagem no específico sentido de que pode identificar-se um idioma e compilar-se uma lista de significados. Embora reconheça que um dicionário completo da linguagem musical seja dificilmente construível, Cooke fornece por assim dizer um phrase-book da música ocidental de base tonal.

O problema é que o carácter natural da relação proposta (um significado inerente percebido através dos ouvidos; uma manipulação de vibrações sensorialmente perceptíveis em relação com uma estrutura de base neurobiológica) faz presumir a sua universalidade e, portanto, o seu carácter a-histórico. No entanto, muitos autores têm sublinhado que a escala musical ocidental não é única, não é natural, nem se funda nas leis de constituição do som. Pelo contrário, nas palavras de A. J. Ellis "a escala musical ocidental é muito artificial e caprichosa” (1985: 526). A verdade é que as regras da música "não são leis no sentido físico mas convenções que os músicos acordaram" (Davis, 1978: 15). Para o ouvido ocidental, a escala diatónica (dó, ré, mi, etc.) é considerada, não apenas normal, mas a base natural da organização musical e qualquer excerto musical construído com base noutros princípios (melódicos e harmónicos) torna-se difícil e pouco inteligível. Por exemplo, é raro tocar e difícil cantar intervalos inferiores a meio-tom, ainda que isso seja possível e praticado noutras culturas musicais. Embora a generalidade dos instrumentos musicais utilizados no quadro do repertório da tradição erudita ocidental permitam executar intervalos inferiores a meio tom, a verdade é que, na aprendizagem de tais instrumentos, se é treinado a não o fazer (por exemplo, controlando a intensidade do sopro no caso dos metais), e o cravo, o órgão e o piano (instrumento de excelência nas actuais execuções desta tradição) não permitem de todo em todo executar tais intervalos. Para além disso, as formas tradicionais de notação musical (pautas) não o prevêem e, por outro lado, as chamadas leis da harmonia só num passado relativamente recente foram adoptadas e apenas na tradição musical (já não só erudita) da civilização ocidental. Por outras palavras, a forma como a padronização dos sons se organiza em música nas diferentes sociedades é resultado de processos culturais e não de quaisquer determinações acústicas ou naturais. Em suma, o que para os Ocidentais parece um elemento essencial da música acaba por ser uma convenção socialmente construída e poderosamente estabelecida. Na análise sócio-histórica de Max Weber (1998), a construção de um sistema de notação musical, o processo de construção da escala tonal temperada e o 
aturado desenvolvimento da harmonia, que caracterizam a erudita tradição musical ocidental, correspondem globalmente à emergência e sedimentação do processo de racionalização que caracteriza essa mesma civilização. No essencial, a argumentação de Weber responde ao seguinte questionamento: porque é que a harmonia musical, sendo uma característica da maior parte das polifonias de cariz popular, conhece particular desenvolvimento na Europa?

De qualquer modo, não existe uma contradição inultrapassável entre tais posições, ou seja: à predisposição de base neuro-sensorial (inata e a-histórica) pode justapor-se a complexidade de estruturas e arranjos musicais culturalmente construídos. Mas remanesce o problema de perceber como é que, numa dada cultura, determinados significados se associam a certos padrões sonoros. Se o paralelismo com a linguagem verbal (escrita e falada) é permitido, vale a pena sublinhar que a aprendizagem de uma língua não se resume ao desenvolvimento de uma capacidade técnica para comunicar, simultaneamente absorvem-se conceitos, categorias e formas cognitivas da cultura que nos envolve. Quando crianças, não criamos uma linguagem, aprendemos as linguagens que nos cercam, aceitando os padrões de pensamento que implicitamente transmitem. Mais, é na interacção com os outros, através das suas reaç̧ões, que se aprendem as noções prevalecentes do certo e do errado, do mais e do menos eficaz, etc. As pessoas vão-se tornando competentes e confiantes participantes numa comunidade linguística, todavia apenas alguns serão capazes de especificar as regras da correcta utilização que o seu discurso pressupõe e, mesmo entre peritos, tais matérias são frequentemente discutidas e não consensuais. Ora, a familiarização com a linguagem musical através da socialização provavelmente não é um processo muito distinto do que se passa com a linguagem.

No entanto, segundo Jean-Jacques Nattiez (1971), a relação entre significante e significado na música não é directamente comparável ao que se passa na linguagem, na medida em que cada um reage a uma obra musical de acordo com as respectivas idiossincrasias, anteriores experiências e recordações. Apesar disso, Nattiez reconhece que, numa população culturalmente homogénea, as reacções provocadas pela música são relativamente estritas, sendo possível identificar relações estatisticamente válidas entre diversos fragmentos musicais e as formas como são interpretados ou os seus respectivos significados. O já referido trabalho de Deryck Cooke (1989) consiste, aliás, numa elucidação dos processos ali envolvidos no plano dos códigos intra-musicais (cf. supra). Por seu turno, Chistian Béthune debruçou-se sobre músicos de jazz e exemplifica a transmissão de significados através da citação musical: por vezes, a citação musical constitui uma dedicatória 
ou presta uma homenagem; noutros casos, capitalizando conteúdos semânticos não estritamente musicais, por exemplo, os títulos das obras, a citação musical permite transmitir informação entre músicos sem que o público se dê conta: bastará evocar a melodia de Ain't She Sweet para indicar que chegou uma bela mulher, uma réplica que evoque Love For Sale indicará que a mensagem foi percebida e que o comportamento dessa mulher é venal (Béthune, 1998: 104).

Em qualquer dos casos, o que importa sublinhar é que as relações referidas por Nattiez ou as propostas por Cooke, assim como a comunicação através de citações sublinhada por Béthune, implicam uma partilha de culturas musicais. Como diz R. Scruton (1983), o significado da música nem lhe é inerente nem decorre de meras intuições, o sentido atribuído à música surge fundamentalmente como consequência da actividade de grupos de pessoas em determinados contextos culturais. A forma como se empresta sentido à música não é inata mas depende da aquisição de conhecimentos comuns, de ideias tidas por certas relativamente a como devia soar. Em cada cultura, alguns padrões convencionais de som organizado tornam-se aceites como normais ou mesmo naturais. Leonard Meyer vai mais longe sugerindo que é na medida em que os compositores assumem uma cultura musical partilhada que podem prever os efeitos que a sua música terá no público e planear o seu trabalho de acordo com isso (Meyer, 1970: 40-41). Seguindo Meyer, também Howard Becker sublinha que as respostas ao mundo artístico devem compreender-se como decorrentes da capacidade dos artistas de manipular as expectativas da audiência: "Apenas na medida em que artista e público partilham conhecimento e experiência com as convenções evocadas é que o trabalho artístico produz efeitos emocionais" (Becker, 1982: 30). Do ponto de vista da manipulação dos sons em movimento (música), trata-se de jogar com progressões melódicas ou harmónicas que geram tensão (por atenção à escala em que o tema se estrutura e repousa) e criam expectativas, na medida em que se retarda a sua resolução, e que produzem acordo musical (harmónico) e satisfação emocional quando a progressão regressa ao tom dominante.

Dir-se-ia que, uma vez socializados e familiarizados com determinadas formas e estruturas convencionais, músicos e ouvintes confrontam-se com um mundo musical que lhes parece normal, organizado e pouco ou mesmo não problemático. Como Pierre Bourdieu insistentemente relembra, uma vez que as configurações culturais estão estabelecidas, elas passam a ser assumidas como naturais (Bourdieu, 1972, 1979). O facto de, em qualquer cultura, as pessoas associarem certos sons a certos significados sociais é inevitável se efectivamente existe algum tipo de prática social chamada 
música. No entanto, isso não significa que qualquer associação particular seja necessária ou natural. Em suma, a possibilidade de partilhar sentido e comunicar significados pressupõe uma comunidade de pessoas que, em resultado de uma socialização, partilham quadros de referência mais ou menos comuns que lhes fornecem um conhecimento tido por certo (Schutz, 1972: 74), ou, nas palavras de Meyer (1970), as expectativas adequadas para interpretar o que se ouve de forma culturalmente competente.

Por outro lado, a socialização musical não reside apenas no envolvimento directo com a música (ouvindo ou praticando), mas em todas as formas de relacionamento com ela, designadamente as diferentes modalidades de interacção social em que se ouve, pratica e também se discursa sobre música. Músicos, professores, críticos da especialidade e também os públicos frequentemente discursam sobre música, o que não deixa de ter efeitos recíprocos no tocante às percepções e representações sobre a música, embora ninguém esteja obrigado a subscrever as teses defendidas por outros, aliás, muitas vezes contraditórias. De qualquer modo, também no plano discursivo vão sendo fornecidas formas possíveis (e, por vezes, dotadas de alguma autoridade) de pensar, ouvir e sentir música. Segundo Alexandre Melo, a importância do papel cultural dos críticos de arte (e, mais genericamente, dos intermediários culturais), enquanto geradores de opinião deve-se à "cumplicidade vivencial e intelectual com uma comunidade artística, à cumplicidade analítica e de sensibilidade entre uma prática de escrita e o conhecimento de um conjunto de obras" (Melo, 1994: 58-59). Seja como for, a verdade é que vigora um consenso implícito relativamente à ideia de que vale a pena argumentar e discutir sobre o sentido e o valor da música, seja nos planos estético e emocional, seja nos planos cultural e social. De facto, tais assuntos revelam-se bastante importantes para muitas pessoas e os debates são frequentemente intensos, e participar num debate é partilhar um mundo cultural, partilhar pressupostos sobre a natureza da música e os conceitos com os quais ela pode ser compreendida.

Seguindo a perspectiva desenvolvida pelas teorias da recepção, pode argumentar-se que nem a linguagem comum nem a comunicação musical devem entender-se como veículos através dos quais uma mensagem sem ambiguidade passa de um transmissor a um receptor. À semelhança do emissor, também o receptor tem um papel activo na atribuição de sentido aos sons organizados de acordo com as convenções linguísticas ou musicais; o significado da música depende, pois, tanto de procedimentos interpretativos do ouvinte como do trabalho do compositor.

Theodor W. Adorno empenhou-se em afirmar o carácter ideológico da música, equacionando as funções simbólicas que nessa perspectiva lhe estão 
adstritas. Não obstante, relativamente às hodiernas sociedades ocidentais, em que a música já não parece desempenhar um papel predeterminado em situações sociais específicas, Adorno escreveu:

[...] a música existe com função de divertimento. [...] Ela presta-se particularmente a isso, em virtude de a sua não conceptualização permitir em larga medida aos auditores sentirem-se seres sensíveis na sua companhia, fazer associações de ideias, imaginar o que no momento desejam. Ela assegura funções de realização de desejo e satisfação. (Adorno, 1970: 7-8)

Segundo Tia DeNora (1986), é a própria indeterminação do significado musical que permite e amplia a variabilidade de atribuições (e vivências) de sentido. Também aqui se sublinha que o significado da música nem lhe é inerente nem decorre de inerentes capacidades cognitivas da espécie humana. Os significados são gerados no processo comunicativo da interacção entre pessoas (e não são menos reais por isso) e, em virtude de uma formação formal ou de experiências informais, aprende-se a ouvir música enquanto padrões de som coerentes e significativos, do mesmo modo que se aprende a atribuir sentido a tudo o mais no mundo social. Mais, importa enfatizar a ideia de que a construção de sentido sobre objectos e práticas musicais ocorre através da actividade de indivíduos e grupos na medida em que praticam, perseguem e desenvolvem os seus gostos, preferências e interesses. A construção de sentido e a negociação que ela envolve são parte constitutiva da vida quotidiana e, como diz DeNora, "a cultura representa uma luta sobre a definição da realidade social e por isso o problema dos significados dos objectos é também o problema de quem os define ou deles se apropria, aonde, quando, como e com que objectivo" (DeNora, 1986: 93).

Perante a diversificada panóplia de teses e argumentos desenvolvidos por músicos, críticos, analistas e outros nos seus vários debates e disputas não cabe à sociologia arbitrar o problema do sentido ou do valor da música, sejam ele e ela quais forem, mas sim examinar o contínuo processo de construção, conflito e negociação de sentidos. Dito de outro modo, o que as pessoas dizem sobre música e o que para ela reivindicam deve tratar-se como informação relativa às suas convicções e crenças sobre ela. Crenças que são, obviamente, importantes elementos de qualquer cultura e são também uma das bases sobre as quais as pessoas formulam linhas de envolvimento e acção. Segundo Max Weber (1998), o objectivo da sociologia da arte não implica a produção de juízos de valor relativos à estética. Implica, isso sim, aceitar que o trabalho artístico existe e tentar compreender como e porque é que as pessoas orientam as suas condutas em relação a tais arte- 
factos. Como ensina a epistemologia interpretativa de Weber, a acção humana não é apenas uma resposta a estímulos externos, uma vez que é formulada com base nos significados que adquire para os actores. A sociologia da música não deverá, pois, preocupar-se com procurar algum verdadeiro significado de uma obra, mas sim interessar-se pelo que as pessoas acreditam que significa, porque é este significado que influencia as suas respostas, a forma como a praticam e com ela se relacionam.

A ideia de que a comunicação de sentido na música implica uma comunidade de ouvintes conhece algumas importantes implicações, particularmente no quadro das sociedades ocidentais devido à elevada diferenciação interna que as caracteriza. De facto, a normal experiência de socialização fornece à maioria das pessoas expectativas gerais e porventura difusas (mas nem por isso menos poderosas) sobre a natureza da música. Mas esse conhecimento subliminar pode ser conscientizado e incrementado através de aprendizagens formais ou informais e, consequentemente, gerar grupos com conhecimentos especializados ou mesmo grupos de peritos (compositores, intérpretes, professores, críticos, assim como amantes de música de todos os géneros). Tais grupos podem ser bastante diferenciados de acordo com os tipos de música pelos quais mais se interessam, e cada um dos grupos ou subgrupos pode ser visto como uma comunidade de ouvintes ou de fruidores musicais.

Neste contexto, vale a pena sublinhar que os diversos géneros musicais não representam apenas diferentes opções num sentido meramente técnico (ou musical em sentido estrito), mas são gerados e reproduzidos por grupos de pessoas com diferentes propensões emocionais e comunicativas, diferentes gostos e interesses estéticos, diferentes projectos e distintas posições nos campos cultural e social, e, acrescente-se, com diferentes combinações destas dimensões. Sabe-se, aliás, que o gosto musical não vive solteiro. Segundo Pierre Bourdieu, é mesmo uma das formas como mais inequivocamente se expressam as pertenças sociais de classe (1979: 17). Sem pretender pôr em causa o essencial desta afirmação, valerá a pena notar que ela foi subscrita a propósito de um determinado contexto social, cultural e temporal (a sociedade francesa em finais dos anos setenta), e por atenção a processos de distinção social cujos contornos são justamente variáveis ao longo do tempo e dos contextos socioculturais. Ora, sobretudo a partir dos anos oitenta, alguns estudos evidenciaram um progressivo eclectismo no gosto das classes dominantes, em particular no domínio musical. Seguindo Philippe Coulangeon (2003), o que distingue o comportamento das classes dominantes é menos a familiaridade com a cultura "legítima" (e a virtual distinção que dai decorreria) do que a diversidade de preferências, ao passo 
que as classes populares denotam preferências francamente menos eclécticas, sendo aqui que se encontra o maior número de amadores exclusivos, dos quais os fãs representam o caso extremo.

A incursão no debate de alguns problemas a propósito dos seus sentidos permitiu sugerir que a música pode ser muitas coisas, não apenas no plano das experiências sensoriais e emocionais, mas também nos planos cognitivo, perceptivo e projectivo, e certamente também nos planos cultural e social que informam e de algum modo formatam aqueles.

\section{Os músicos como objecto sociológico}

Querendo agora centrar a discussão no grupo dos músicos profissionais (compositores e intérpretes), valerá a pena começar por perceber como é que os músicos se tornam músicos, como se iniciam e se envolvem no meio musical. Alguma forma de aquisição de competências musicais constitui certamente uma condição necessária, mas sabe-se que os espaços dessa aprendizagem podem ser muito diferenciados: desde contextos informais, como o autodidactismo e os grupos de amigos, geralmente assentes numa transmissão oral de conhecimentos baseada nas competências do chamado ouvido, e mais ou menos complementada por manuais de iniciação, a contextos de aprendizagem fortemente formalizados, que permitem obter certificações diplomadas, e que não dispensam o conhecimento teórico dos códigos musicais e a sua transposição para uma notação escrita. Em qualquer caso, importa sublinhar que ser músico não decorre apenas de uma competência técnica. É necessário fazer parte de uma rede de relações sociais para que tenham lugar os processos de iniciação, primeiro, e os processos de aquisição de competências musicais e eventual profissionalização, depois. Em que medida, por exemplo, os contextos sociofamiliares de origem desempenham um papel relevante na iniciação musical e mesmo na configuração das relações com a música? Como se constituem e desenvolvem essas relações e quais são os elementos determinantes na opção por determinado género musical? Ou quais as circunstâncias determinantes de uma profissionalização, assim como da sua continuidade e mesmo do seu eventual sucesso?

Segundo um reputado maestro e compositor, embora chegue ao conhecimento do público individualmente assinada, a própria inovação musical ocorre no seio de uma comunidade de músicos e não em génios solitários: "A verdadeira vocação de um compositor cresce em contacto com outros compositores" (Boulez, 1992:53). Os estudos de David Aronson (1982) ou de K. A. Cerulo (1984) mostram isso mesmo, ou seja, que a evolução e a inovação são geralmente resultado de grupos que partilham a mesma pers- 
pectiva, e que mesmo o compositor aparentemente solitário deve ser visto como operando no seio de um contexto social específico, uma comunidade de músicos, ou, nas palavras de Becker (1982) um art world, no qual certas convenções e expectativas se estabelecem e exercem um controlo normativo sobre o processo de produção musical.

A este propósito, Samuel Gilmore introduz uma útil distinção entre o que chama escolas de actividade e escolas de pensamento (1988: 206). As últimas são escolas em que os artistas são filiados pelos críticos, teóricos e historiadores, com base em supostas similaridades do seu trabalho, mas que não pressupõem a existência de grupos sociais reais. Ao contrário, as primeiras referem-se a grupos sociais reais, na medida em que são constituídas pelo conjunto de participantes num qualquer art world à medida que desenvolvem e mantêm práticas comuns entre especialistas interdependentes. Enquanto as escolas de actividade constituem importante grupo de referência e as identidades artísticas aí geradas se revelam cruciais para a realização de performances, as escolas de pensamento revelam-se menos importantes (Gilmore, 1988: 208-9). No seu estudo, Gilmore identificou em Nova Iorque três submundos distintos relativos à execução de obras no quadro da tradição erudita ocidental, cada um representando uma escola de actividade alternativa e sendo portador de um distinto conjunto de convenções. Cada um destes três submundos funciona como grupo de referência e o reconhecimento como participante (musicalmente activo como intérprete ou compositor) implica uma orientação do indivíduo para as respectivas convenções, onde diferentes perspectivas e valores estéticos, competências musicais e preferências performativas são sistematicamente geradas pela especificidade dos processos socioculturais actuantes em cada mundo artístico.

Embora se situem profissionalmente na esfera da produção musical, compositores e intérpretes não deixam de ser também passíveis de uma avaliação enquanto receptores, quiçá com importantes especificidades decorrentes de serem participantes activos e elementos interdependentes no meio social em que a música se gera. E faz sentido perguntar que condições e circunstâncias formatam a construção das identidades sociomusicais destes profissionais. $\mathrm{O}$ estudo de Gilmore evidencia que, mesmo no seio de um mesmo género musical (a tradição erudita da música ocidental, neste caso), é possível detectar configurações distintivas de práticas, valores e representações relativos às formas de viver a música. Nos planos da recepção e consumo, esta questão tem sido tratada e as referências à importância das pequenas diferenças intra-género musical são frequentes e reputadas de significativas. Por exemplo, António Pinho Vargas refere-se a este pro- 
blema sugerindo que os fãs dos Rolling Stones teriam maior aversão aos Beatles do que, por exemplo, a Sinatra ou a Karajan, de quem nem sequer falavam (2002: 334). Nas palavras de Antoine Hennion (1981: 226):

Ao classificar géneros, os ouvintes classificam-se a si próprios. [...] um grupo de amantes de $p \circ p$ fará distinções muito finas no interior desse mesmo género, e agrupará as variedades francesas em duas ou três categorias homogéneas; inversamente, um jovem auditório popular e feminino dará conta de um vasto leque de contrastes entre os ídolos de variedades, relegando o conjunto da música pop para uma rubrica marginal destinada a especialistas, ao lado do jazz e da música clássica.

Falar em diferentes géneros musicais remete certamente para diferentes códigos intra-musicais, mas remete também para diferenças socioculturais que habitualmente lhes estão adstritas. Tais diferenças são relativamente claras no quadro de uma análise sobre o funcionamento social das músicas que focalize as grandes tendências, a forma como elas operam institucionalmente com o todo social, que focalize, por exemplo, os locais em que uma peça sinfónica é tocada e quem a ouve, por comparação com os locais em que actua um grupo de rock e quem assiste. Ou que questione as relações destas (entre outras possíveis) formas musicais com o mercado, com a indústria e com o Estado. Se passam ou não nas estações de Rádio e nos canais de Televisão, em quais e em que horários? E mesmo que comportamentos se associam a umas e outras? E assim por diante. No entanto, tais diferenças não são directamente transponíveis para um contexto de análise indivíduo a indivíduo, quer este pertença aos universos da produção ou da recepção musicais. A este nível, haverá certamente espaço para múltiplas variantes e combinações.

Retomando o enfoque sobre os próprios músicos, uma questão que naturalmente se coloca consiste em saber quais os exactos termos da relação entre os diversos géneros musicais e os distintos contextos de aprendizagem e patamares de competências musicais, quer nas suas componentes mais técnicas ou especificamente musicais, quer nas suas componentes socioculturais. Todavia, uma comparação de diferentes géneros musicais, que designadamente inclua a tradicional distinção entre géneros mais eruditos e mais populares, provavelmente implica adoptar uma malha analítica porventura menos pormenorizada e mais abrangente, ou seja, menos atenta aos contornos de pequenas diferenças, às idiossincrasias deste ou daquele artista (que, justamente, se mostram relevantes nas diferenciações intra-género), e mais atenta a diferenças que se situam num plano mais institucionalizado, diferenças que sendo relativas a dimensões objectivas e subjectivas presen- 
tes na actividade musical profissional, são relevantes na emergência, sedimentação e desenvolvimento dos distintos géneros musicais, ou seja, nos respectivos processos de institucionalização.

Mas, para além dos distintos géneros musicais que dominantemente praticam (escolas de pensamento, seguindo a terminologia de Gilmore cf. supra), em que é que os músicos profissionais se diferenciam entre si? Que diferenças existirão no tocante às relações que estabelecem com a música (com a sua prática, os seus usos, as formas como a pensam, sentem e vivem, ou as formas como ela se institui em veículo de um projecto)? Falar em formas de viver (fazer, sentir, lidar e pensar) a música remete afinal para falar das relações que, em diferentes planos, se estabelece com ela. Mas, perante tal diversidade e cruzamento de planos, será possível encontrar alguns princípios heurísticos capazes de equacionar melhor visibilidade sobre tal heterogeneidade?

\section{Conclusão}

O percurso seguido neste artigo sugere que a música pode ser muitas coisas. Não apenas porque constitui um universo bastante diversificado (compreendendo múltiplos estilos, cambiantes e géneros musicais), mas também porque as pessoas se relacionam com ela em moldes muito diversos, ou seja, são múltiplas as formas como as pessoas (quer as pessoas em geral, quer os seus profissionais) interagem com a música.

Embora conheça alguns relevantes contributos (por exemplo, o estudo sobre amantes de música académica desenvolvido por Hennion et al., 2000), a tarefa de restituir tal heterogeneidade, parametrizando sociologicamente a diversidade de formas de viver a música, nas suas múltiplas variantes, incluindo a distinção entre formas culturais mais populares e mais eruditas, encontra-se ainda por fazer, designadamente no que respeita aos músicos, mas também no que respeita aos públicos, muitas vezes apenas dirimidos numa repartição por categorias que decorem de critérios muito parciais (por exemplo, critérios relativos aos suportes utilizados na audição, critérios relativos ao tipo de espaços em que a audição ocorre, ou, mais simplesmente, organizados em função de categorias sociográficas [Abreu, 2004]).

Embora focalizado empiricamente sobre músicos profissionais, mas no sentido de parametrizar aquela heterogeneidade e de dar resposta ao questionamento que encerra o ponto 4 ( cf. supra), desenvolveu-se um estudo baseado na hipótese de que os diferentes géneros musicais se associam a diferentes modos de relação com a música. Não é aqui oportuno substantivar os termos da relação proposta (géneros musicais e modos de relação com a música) assim com os contornos das suas articulações, mas pode 
adiantar-se que o conceito de modos de relação com a música compreende três planos conceptuais $(1-$ competências e contextos de aprendizagem musicais; 2 - importância relativa da música no contexto da performance musical; e 3 - papéis da música nas relações consigo, com o público e em sociedade), que organizam treze dimensões analíticas susceptíveis de operacionalização para efeitos de observação de situações empíricas e permitem tipificar qualitativamente as modalidades da fruição musical equacionando-a em torno de dois pólos: o essencial (privilégio de factores intrinsecamente musicais) e o relacional (privilégio de factores extrínsecos ou não intrinsecamente musicais) (Campos, 2007).

No essencial, tratou-se de aprofundar de modo integrado um conjunto diversificado de relações específicas às práticas musicais, internalizando dimensões e mediações inerentes à sua prática e tipificando qualitativamente as diferentes modalidades da sua fruição, designadamente quando se perspectiva a música nas suas dimensões mais institucionalizadas. Tratou-se, em síntese, de substantivar a relação que os músicos estabelecem com a música, parametrizando a estrutura de disposições (estruturadas e estruturantes) mais directamente implicadas no campo musical, e potenciando assim uma avaliação quer dos contextos de actualização do babitus (nos planos cognitivo, relacional e reflexivo), quer enquanto elemento constitutivo dos processos sociais implicados numa produção cultural com grande projecção mediática. O conceito de modos de relação com a música revela-se, aliás, adequado para analisar a fruição musical quer relativamente aos seus produtores (compositores e intérpretes), quer por atenção aos consumidores (embora aqui com necessárias adaptações), mas trata-se de matérias desenvolvidas noutro lugar (Campos, 2007a, 2007b).

\section{Referências bibliográficas}

AA.VV. (1971), "Dossier débat: musique e politique", Musique en Jeu, 3.

Abreu, Paula (2004), "Ouvir, comprar, participar... Acerca da reciprocidade cumulativa das práticas musicais”, in Públicos da Cultura. Lisboa: Observatório das Actividades Culturais.

Adorno, Theodor W. (1970), "Réflexions en vue d'une Sociologie de la Musique", Musique en Jeu, 7 [1958].

Almeida, António Victorino d' (1993), Música. Lisboa: Difusão Cultural.

Aronson, David (1982), "Le jazz: une musique en exil”, Revue Internationale des Sciences Sociales, $\operatorname{xxxiv}(4)$.

Becker, Howard S. (1982), Art Worlds. Berkeley: University of California Press.

Béthune, Chistian (1998), "Imitação e criação em Jazz", O papel do Jazz, 3. 
Boehmer, K. (1980), “Sociology of Music”, in S. Sadie (org.), The New Grove Dictionary of Music and Musicians. London: Macmillan.

Boulez, Pierre (1992), A Música Hoje 2. São Paulo: Editora Perspectiva.

Bourdieu, Pierre (1972), Esquisse d'une théorie de la pratique. Genève: Librairie Droz.

Bourdieu, Pierre (1979), La distinction: Critique sociale du jugement. Paris: Les Editions de Minuit.

Bowler, Anne (1994), "Methodological Dilemmas in the Sociology of Art”, in Diana Crane (org.), The Sociology of Culture. Emerging Theoretical Perspectives. Oxford/Cambridge, MA: Blackwell.

Campos, Luís Melo (2007a), Músicas e músicos: modos de relação. Lisboa: Celta Editora (no prelo).

Campos, Luís Melo (2007b), "Modos de relação com a música”, Sociologia. Problemas e Práticas, 53.

Candé, Roland de (2003), História Universal da Música. Porto: Afrontamento.

Carvalho, Mário Vieira de (1991), "Sociologia da Música. Elementos para uma retrospectiva e para uma definição das suas tarefas actuais", Revista Portuguesa de Musicologia, I.

Cerulo, K. A. (1984), "Social Disruption and its Effects on Music - An Empirical Analysis”, Social Forces, 62.

Cooke, Deryck (1989), The Language of Music. Oxford: Oxford UP.

Coulangeon, Philippe (2003), "La stratification sociale des goûts musicaux. Le modèle de la légitimité culturelle en question", Revue Française de Sociologie, 44-1.

Crane, Diana (1994), "Introduction: The Challenge of the Sociology of Culture to Sociology as Discipline", in Diana Crane (org.), The Sociology of Culture. Emerging Theoretical Perspectives. Oxford /Cambridge, MA: Blackwell.

Davis, John B. (1978), The Psychology of Music. London: Hutchinson.

DeNora, Tia (1986), "How Is Extra-Musical Meaning Possible? Music as Place and Space for 'Work'”, Sociological Theory, 4.

Eco, Umberto (1972), A definição da arte. Lisboa: Edições 70.

Ellis, A. J. (1985), "On the Musical Scales of Various Nations", Journal of the Society of Arts, 33.

Gilmore, Samuel (1988), "Schools of Activity and Innovation”, Sociological Quarterly, 29.

Grout, Donald J.; Palisca, Claude V. (1997), História da música ocidental. Lisboa: Gradiva.

Hanslick, Eduard (s/d), Do belo musical. Lisboa: Edições 70 [1854].

Hennion, Antoine (1981), Les professionnels du disque. Paris: Editions A.M. Métailié.

Hennion, Antoine (1993), La passion musicale. Paris: Editions A.M. Métailié.

Hennion, Antoine et al. (2000), Figures de l'amateur. Formes, objets et pratiques de l'amour de la musique aujourd'bui. Paris: La Documentation Française.

Herzfeld, Friedrich (s/d), Nós e a música. Lisboa: Livros do Brasil. 
Langer, Suzanne (1969), Philosophy in a New Key. Cambridge: Harvard UP.

Martin, Peter J. (1995), Sounds and Society: Themes in the Sociology of Music. Manchester: Manchester UP.

Melo, Alexandre (1994), Arte. Lisboa: Difusão Cultural.

Melo, Alexandre (2000), "Entrevista com Alexandre Melo”, Notícias Magazine.

Merriam, Alan P. (1964), The Anthropology of Music. Evanston: Northwestern UP.

Meyer, Leonard (1970), Emotion and Meaning in Music. Chicago: Chicago UP.

Moles, Abraham (1958), Théorie de l'information et perception esthétique. Paris: Flammarion.

Nattiez, Jean-Jacques (1971), "Situation de la sémiologie musicale”, Musique en Jeu, 5.

Peterson, Richard A. (1994), "Culture Studies through the Production Perspective: Progress and Prospects”, in Diana Crane (org.), The Sociology of Culture. Emerging Theoretical Perspectives. Oxford, UK/Cambridge, USA: Blackwell.

Press, Andrea L. (1994), “The Sociology of Cultural Reception: Notes toward an Emerging Paradigm”, in Diana Crane (org.), The Sociology of Culture. Emerging Theoretical Perspectives. Oxford /Cambridge, MA: Blackwell.

Schutz, Alfred (1972), The Phenomenology of the Social World. London: Heinemann Educational.

Scruton, R. (1983), The Aesthetic Understanding. Manchester: Carcanet Press.

Small, Christopher (1998), Musicking. The Meaning of Performing and Listening. London: Wesleyan UP.

Vargas, António Pinho (2002), Sobre música. Ensaios, textos e entrevistas. Porto: Afrontamento.

Weber, Max (1998), Sociologie de la musique. Paris: Éditions Métailié. 